University of Nebraska - Lincoln

DigitalCommons@University of Nebraska - Lincoln

Mammalogy Papers: University of Nebraska

State Museum

Museum, University of Nebraska State

$11-20-1981$

\title{
Electrophoretic and Immunological Studies on the Relationship of the Brachyphyllinae and the Glossophaginae
}

\author{
Robert J. Baker \\ Texas Tech University, rjbaker@ttu.edu \\ Rodney L. Honeycutt \\ Pepperdine University, rodney.honeycutt@pepperdine.edu \\ Michael L. Arnold \\ University of Georgia \\ Vincent M. Sarich \\ University of California - Berkeley \\ Hugh H. Genoways \\ University of Nebraska - Lincoln, h.h.genoways@gmail.com
}

Follow this and additional works at: https://digitalcommons.unl.edu/museummammalogy

Part of the Biodiversity Commons, Immunology of Infectious Disease Commons, Other Ecology and Evolutionary Biology Commons, and the Zoology Commons

Baker, Robert J.; Honeycutt, Rodney L.; Arnold, Michael L.; Sarich, Vincent M.; and Genoways, Hugh H., "Electrophoretic and Immunological Studies on the Relationship of the Brachyphyllinae and the Glossophaginae" (1981). Mammalogy Papers: University of Nebraska State Museum. 68.

https://digitalcommons.unl.edu/museummammalogy/68

This Article is brought to you for free and open access by the Museum, University of Nebraska State at DigitalCommons@University of Nebraska - Lincoln. It has been accepted for inclusion in Mammalogy Papers: University of Nebraska State Museum by an authorized administrator of DigitalCommons@University of Nebraska Lincoln. 


\title{
J OURNAL OF MAMMAL OGY
}

Published Quarterly by the American Society of Mammalogists

VOL. 62

20 November 1981

No. 4

\section{ELECTROPHORETIC AND IMMUNOLOGICAL STUDIES ON THE RELATIONSHIP OF THE BRACHYPHYLLINAE AND THE GLOSSOPHAGINAE}

\author{
Robert J. Baker, Rodney L. Honeycutt, Michael L. Arnold, \\ Vincent M. Sarich, and Hugh H. Genoways
}

\begin{abstract}
Electrophoretic and albumin immunological data indicate that the Brachyphyllinae as currently conceived is a natural assemblage, with Erophylla sezekorni and Phyllonycteris aphylla being more closely related to each other than either is to Brachyphylla cavernarum. In both data sets, values that distinguish Erophylla from Phyllonycteris are in the general range of values that characterize congeneric species of mammals. Immunological distance values for the species Glossophaga soricina, Monophyllus redmani, Anoura caudifer, Leptonycteris sanborni, Choeroniscus minor, and Hylonycteris underwoodi indicate that these taxa are approximately equidistant from the Brachyphyllinae. Immunological comparisons of Glossophaga and Monophyllus to Anoura, Leptonycteris, Choeroniscus, and Hylonycteris indicate that the four latter genera are more closely related to Glossophaga and Monophyllus than Glossophaga and Monophyllus are to the genera of the Brachyphyllinae. Values from Lonchophylla thomasi and Lionycteris spurrelli suggest a more distant relationship of these glossophagine genera to the Brachyphyllinae than the other glossophagine genera examined. Our data suggest that a $2 \mathrm{~N}=32, \mathrm{FN}=60$ karyotype like that characteristic of Glossophaga is primitive for a clade including the Brachyphyllinae and the glossophagine genera Anoura, Glossophaga, Monophyllus, Leptonycteris, Hylonycteris, and Choeroniscus. These data suggest that the polyphyletic origin of certain glossophagine genera, as proposed by Baker (1967), is unlikely.
\end{abstract}

This study was designed to provide data on the evolution and systematics of the only endemic subfamily of Antillean bats, the Brachyphyllinae (Phyllostomidae). The evolutionary affinities and number of genera in the Brachyphyllinae (=Phyllonycterinae; see Baker, 1979) has been a persistent source of debate (Silva-Taboada and Pine, 1969; Baker and Bass, 1979). One of the three genera, Brachyphylla, currently placed in this subfamily has been placed in four different subfamilies (Baker and Bass, 1979). Data from G-band chromosomes show that relative to the proposed primitive karyotype for the family Phyllostomidae (Patton and Baker, 1978), Brachyphylla shares a derived karyotype with Erophylla and Phyllonycteris (the other two genera recognized in the Brachyphyllinae). However, this derived karyotype is also shared with two genera (Glossophaga and Monophyllus) of the subfamily Glossophaginae. Therefore, these chromosomal data cannot conclusively document that Brachyphylla is more closely related to Erophylla and Phyllonycteris than to the glossophagine genera Monophyllus and Glossophaga. We address this systematic question using biochemical data from both starch-gel electrophoresis and albumin immunology.

The current chromosomal data for Glossophaga, Monophyllus, and the brachyphyllines can be interpreted in at least two ways. First, the karyotype of the brachyphyllines and Glossophaga and Monophyllus is pleisiomorphic for all glossophagines 
as well as the brachyphyllines, or second, this karyotype is the result of a group of synapomorphic character states that document that some glossophagine genera (Monophyllus, Glossophaga, and possibly others) and the Brachyphyllinae shared a common ancestor after diverging from other glossophagines (as proposed in fig. 8 of Gardner, 1977). The systematic implications of the two alternatives are radically different. In the first case, recognition of the Brachyphyllinae would be justifiable from a phylogenetic standpoint, with the Glossophaginae as a sister taxon. However, the second case would imply that despite the classical anatomical and dental differences that serve as the basis for recognition of the two subfamilies, there would be no phylogenetic basis for recognition of the Brachyphyllinae as a sister taxon to the Glossophaginae (Baker and Bass, 1979). The immunological technique of microcomplement fixation was used to examine the above alternative evolutionary hypotheses.

\section{MATERIALS AND MethodS}

Electrophoretic analysis.-Bats were collected with mistnets from natural populations (species, localities, and sample sizes given under specimens examined). Immediately after sacrifice, liver, kidney, and heart samples were removed and frozen in liquid nitrogen. Techniques for tissue preparation, electrophoresis, and biochemical staining are essentially those described by Selander et al. (1971).

Seventeen isozymes were assayed. These presumed loci were Isocitrate dehydrogenase- 1,2 (Idh-1,2), Malate dehydrogenase-1,2 (Mdh-1,2), Lactate dehydrogenase-1,2 (Ldh-1,2), Leucine aminopeptidase (Lap), Albumin (Alb), Glutamate oxalate transaminase-1,2 (Got-1,2), a-Glycerophosphate dehydrogenase (a-Gpd), 6-Phosphogluconate dehydrogenase (6-Pgd), Hemoglobin (Hb), Indophenol oxidase-2 (Ipo-2), Phosphoglucomutase-2 (Pgm-2), Sorbitol dehydrogenase (Sdh), and Peptidase (Pep). The substrate used to resolve Pep was Glycyl-L-leucine. The most common allele for a given locus was designated -100 if cathodal, 100 if anodal. All other variants are described in percentages of this common allozyme. Loci were designated numerically, with the most anodal isozyme being " 1 " and more cathodal loci being given progressively higher numbers. By using the allozyme data, Rogers' D values (Rogers, 1972) were calculated between the species studied.

Immunology.-Albumins were purified from serum (Glossophaga) and pooled tissues (Brachyphylla, Phyllonycteris, Monophyllus) remaining from the electrophoretic studies. For each albumin, $5 \mathrm{~g}$ of tissue were homogenized in $15 \mathrm{ml}$ isotris buffer, dialyzed against $50 \mathrm{mM}$ Tris $(\mathrm{pH}=8.0)$, and centrifuged. To the supernatant was added $20 \mathrm{mg}$ Rivanol (2-ethoxy 6, 9 diaminoacridine lactate) in $1 \mathrm{ml}$ of the above buffer and the resulting precipitate was separated by centrifugation. The precipitate (mainly a Rivanol-albumin complex) was then treated with 5 $\mathrm{ml}$ of $0.5 \mathrm{M}$ Trizma-HCl until the fine yellow particles of free Rivanol were regenerated. The Rivanol was then separated by centrifugation and the supernatant dialyzed against $0.2 \mathrm{M}$ Trissulfate $(\mathrm{pH}=8.9)$ and vacuum-dialyzed to a volume of $0.7 \mathrm{ml}$. Fifty percent glycerol $(0.2 \mathrm{ml})$ was then added and the albumin isolated by preparative polyacrylamide electrophoresis using the above-mentioned Tris-sulfate buffer for the gel and a Tris-borate electrode buffer (3.2 $\mathrm{g}$ Tris, $0.45 \mathrm{~g}$ boric acid per liter). The acrylamide concentration was $7.5 \%$. The albumin band was identified using ANS (8-Anilino-1-Napthalenesulfonic Acid Magnesium Salt), cut out of the gel, and eluted in $12 \mathrm{ml}$ of isotris buffer. Albumin from Glossophaga was prepared in the same way except that the original dialysis was done on a six-fold diluted serum sample.

Antisera to the albumins of Brachyphylla cavernarum, Phyllonycteris aphylla, Monophyllus plethodon, and Glossophaga soricina were prepared in rabbits (three to four Dutch belted rabbits per albumin) according to the schedule of Sarich (1969). In each case, the antisera to a particular bat species were titered using the microcomplement fixation (MC'F) procedure and pooled in reciprocal proportion to their titers (Sarich and Wilson, 1966). These pooled antisera were used for all subsequent analyses.

Albumins of certain bat species were compared and their corresponding immunological differences calculated using quantitative microcomplement fixation. Immunological differences were reported in albumin immunological distance units (AID) with one unit being approximately equivalent to one amino acid substitution (Prager and Wilson, 1971; Maxson and Wilson, 1974).

Data analysis.-The Fitch and Margoliash (1967) method was used to construct phylogenetic 


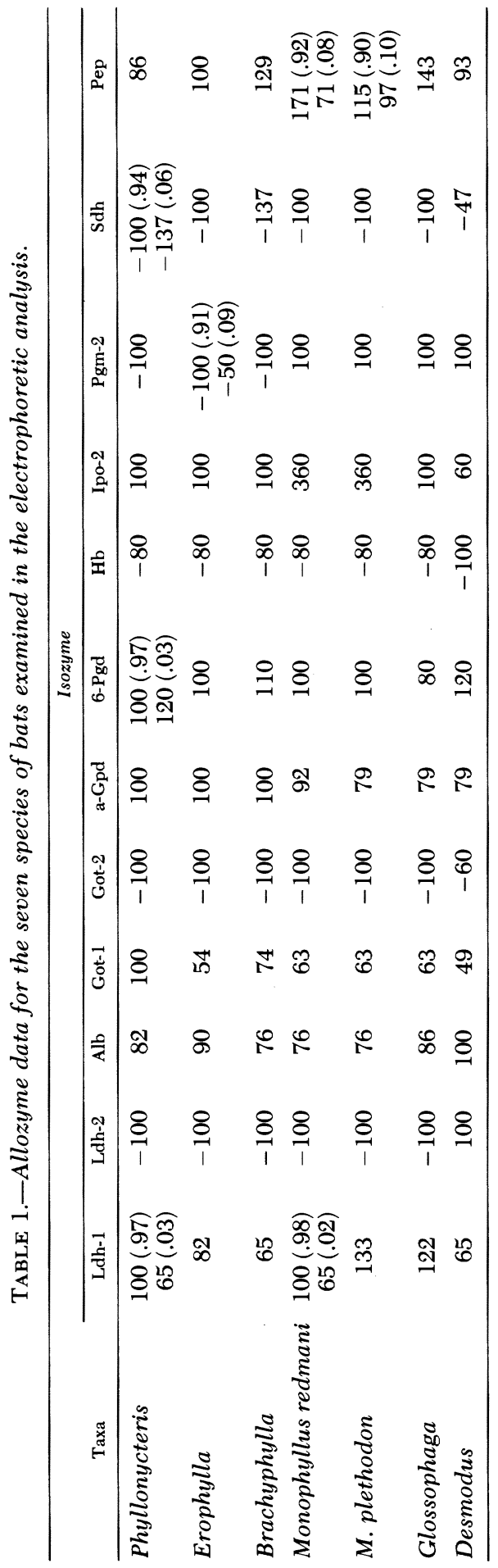


TABLE 2.-Rogers' D values $(\times 100)$ among the seven species of bats examined.

\begin{tabular}{|c|c|c|c|c|c|c|c|c|}
\hline Species & & I & 2 & 3 & 4 & 5 & 6 & 7 \\
\hline Phyllonycteris aphylla & 1 & & 35 & 41 & 24 & 29 & 41 & 67 \\
\hline Monophyllus redmani & 2 & & & 17 & 41 & 41 & 35 & 61 \\
\hline Monophyllus plethodon & 3 & & & & 41 & 47 & 29 & 55 \\
\hline Erophylla sezekorni & 4 & & & & & 36 & 41 & 67 \\
\hline Brachyphylla cavernarum & 5 & & & & & & 47 & 69 \\
\hline Glossophaga soricina & 6 & & & & & & & 57 \\
\hline Desmodus rotundus & 7 & & & & & & & \\
\hline
\end{tabular}

trees from both immunological distance and electrophoretic distance (Rogers' D) values. As indicated by Prager and Wilson (1978), this approach seems to be the most appropriate for immunological and electrophoretic data. Strengths of this approach are as follows: 1) it is an iterative averaging procedure which apportions amounts of change along branch lengths without an assumption of homogeneous rates of evolution; 2) the phylogenetic trees, so constructed, can be evaluated by comparing original input data and output values calculated from the tree (the evaluation used in this study was the $\mathbf{F}$ value introduced by Prager and Wilson, 1978, which is defined as $100 \mathrm{f} / \mathrm{I}$, where $\mathrm{f}$ is the sum of the absolute values of differences between output and input values and $I$ is the sum of the input values); 3) the immunological data can also be tested for nonreciprocity, which represents the percent deviation between immunological distance values calculated from reciprocal antisera. As noted by Cronin and Sarich (1975) and Sarich and Cronin (1976), most of the disagreement between input and output data from the Fitch and Margoliash trees can be accounted for by percent nonreciprocity.

Specimens examined.-Erophylla sezekorni. Jamaica: $1 \delta^{\hbar}$, St. Catherine Parish, $0.2 \mathrm{mi} \mathrm{E}$ Watermount; $1 \%$, Westmoreland Parish, Bluefields; $4 \delta^{\dagger}, 1 \%$, St. Ann Parish, Orange Valley; $5 q \uparrow$, Portland Parish, $0.8 \mathrm{mi}$ W Drapers. Phyllonycteris aphylla. Jamaica: $8 \delta^{\dagger} \delta, 6 q q$, St. Ann Parish, Orange Valley; $2 q \uparrow$, Hanover Parish, Flint River, 1.5 mi E Sandy Bay; 19 , St. Catherine Parish, St. Clair Cave. Brachyphylla cavernarum. Dominica: $3 \delta^{\star} \delta^{\star}, 2 q q$, St. Paul Parish, Stinking Hole; $1 \delta^{\star}$, St. Paul Parish, Springfield. Montserrat: $2 \delta^{\star}, 2 \% \uparrow$, St. Anthony Parish, Belham River, $0.5 \mathrm{mi}$ from mouth of river. Monophyllus redmani. Jamaica: $4 \delta^{\star} \delta$, St. Catherine Parish, $0.2 \mathrm{mi}$ E Watermount; $1 \%$, Westmoreland Parish, Bluefields; $100^{\star} \sigma^{\dagger}, 10 \% q$, St. Ann Parish, Orange Valley. Monophyllus plethodon. Dominica: $1 \delta^{*}$, St. Joseph, $1 \mathrm{mi}$ from mouth of Layou River; $1 \delta^{\star}, 8 \uparrow q$, St. Paul, Springfield. Glossophaga soricina. Venezuela: $2 \delta^{\star} \delta$, Guarico, $45 \mathrm{~km}$ $S$ Calabozo Gallery Forest. Desmodus rotundus. Costa Rica: $1 \delta^{\star}$, San Jose, $41.2 \mathrm{mi}$ SW Canas. Hylonycteris underwoodi. Mexico: $1 \delta^{\star}$, Chiapas, $8 \mathrm{mi}$ N Berrizabal. Leptonycteris sanborni. Sonora: 1 t, $6 \mathrm{mi}$ NW Alamos, Minas Armalillo. Anoura caudifer. Suriname: 10, Brokopondo, 1 km N Rudi Kappelvliegveld. Choeroniscus minor. Suriname: 1 \& , Nickerie, Grassalco. Lionycteris spurrelli. Suriname: $1 \delta$, Nickerie, Grassalco. Lonchophylla thomasi. Suriname: 19 , Brokopondo, Brownsberg Nature Park, 8 km S, 2 km W, Brownswieg.

The following specimens are housed in The Museum, Texas Tech University; all specimens of Brachyphylla, Glossophaga, Desmodus, and Monophyllus plethodon and one specimen each of Erophylla and Phyllonycteris. The remaining Erophylla and Phyllonycteris and all Anoura, Choeroniscus, Lionycteris, Lonchophylla, and Monophyllus redmani are located in Carnegie Museum of Natural History. Specimens of Hylonycteris and Leptonycteris are in the Museum of Vertebrate Zoology, University of California at Berkeley.

\section{RESULTS}

Electrophoretic analysis.-Five of the isozymes (Mdh-1,2, Idh-2, Ldh-1, Lap) examined were monomorphic across all seven taxa. The remaining 12 polymorphic loci and the allozyme variants for each species are listed in Table 1. The matrix of Rogers' $\mathrm{D}$ values are given in Table 2 . From these values we produced the phylogenetic tree shown in Fig. 1. This tree produced the lowest $\mathrm{F}$ value $(5.5 \%)$ of any of the possible phylogenies tested.

It should be noted that the internode shared by Glossophaga and the two species 


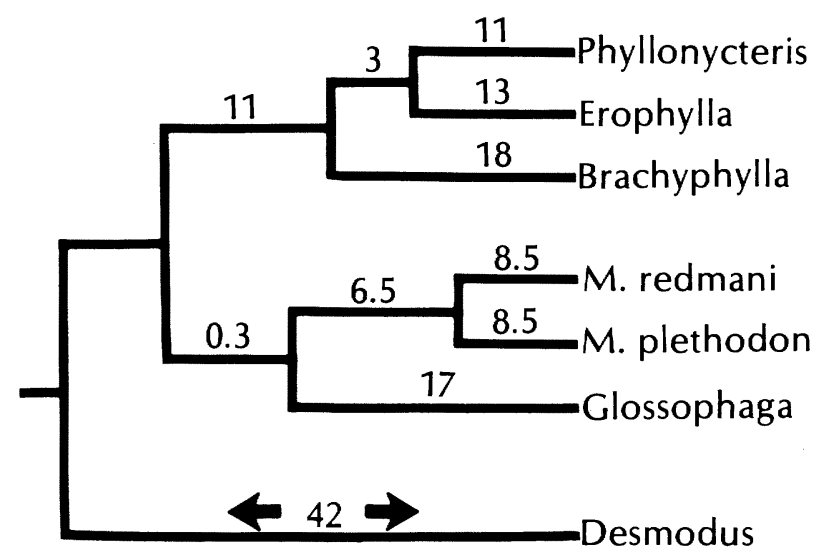

Fig. 1.-Fitch and Margoliash phylogenetic tree constructed using Rogers' D values from the electrophoretic analysis. The $\mathbf{F}$ value is $5.5 \%$.

of Monophyllus represents a value $(\mathrm{D}=0.3)$ that is probably below the level of resolution of the electrophoretic technique. Therefore, this internode could validly be collapsed.

Immunological data.-Reciprocal measurements among the albumins of M. plethodon, P. aphylla, B. cavernarum, and G. soricina were carried out using antisera to each of the four. The nonreciprocity value was $6.6 \%$ before correction and $5.5 \%$ after correction. Amounts of change along the four lineages were assessed using antisera from an outgroup (mixed pool) consisting of six reference albumins: Carollia perspicillata, Micronycteris daviesi, Micronycteris sylvestris, Tonatia silvicola, Vampyrum spectrum, and Phyllostomus hastatus. The Fitch-Margoliash tree developed from these data is presented in Fig. 2.

The albumin immunological distances (AIDs) of E. sezekorni and several glossophagine genera to the four antisera indicated above are in Table 3. Although these estimates of immunological distance represent one-way comparisons, one can attempt to place each of these genera by independently fitting it into the tree shown in Fig. 2. This procedure indicates an association of Erophylla to Phyllonycteris $(\mathrm{F}=5.5 \%)$ resulting in a Phyllonycteris-Erophylla lineage as indicated in Fig. 2. The relative placement for the glossophagine genera plus the "goodness-of-fit" of these genera as assessed using the $\mathrm{F}$ value are as follows: 1) Leptonycteris is associated with the Glossophaga lineage $(\mathrm{F}=7 \%) ; 2)$ Choeroniscus and Anoura are associated with the Monophyllus lineage ( $\mathrm{F}=3 \%$ and $2.5 \%$, respectively); 3 ) the position of Hylonycteris is more tentative and can be placed near the base of either the Glossophaga or Monophyllus lineage; 4) both Lonchophylla and Lionycteris represent independent lineages being separated from all four glossophagine and brachyphylline genera $(\mathrm{F}=$ $2.8 \%$ and $2.1 \%$, respectively). Although the relationships of these two genera cannot be assessed, rate test data from outgroup comparisons (pooled antisera) suggest that the degree of immunological divergence cannot be attributed to differential rates, but rather to a branching off of these genera prior to the common ancestry of the other glossophagine-brachyphylline lineages.

\section{DisCUSSION}

Relationships within the Brachyphyllinae.-Both electrophoretic (Table 2 and Fig. 1) and immunological (Fig. 2) data sets are congruent in defining a brachyphylline clade with Erophylla and Phyllonycteris sharing a more recent common ancestry than 


\begin{tabular}{lrrrrrr} 
& M & B & P & G & O & O \\
Monophyllus & 0 & 32 & 26 & 35 & 37 & U \\
Brachyphylla & 31 & 0 & 24 & 36 & 47 & T \\
Phyllonycteris & 25 & 24 & 0 & 30 & 42 & P \\
Glossophaga & 33 & 36 & 30 & 0 & 50 & U \\
Outgroup & 39 & 47 & 43 & 51 & 0 & T \\
& \multicolumn{7}{c}{ INPUT } & &
\end{tabular}

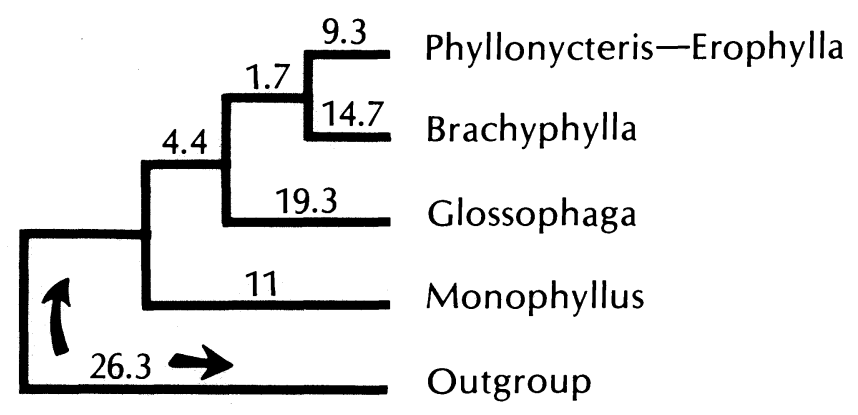

FIG. 2.-Albumin phylogeny of Glossophaga, Monophyllus, and the brachyphyllines relative to the outgroup indicated in the Results. The input values of AID represent the original distance matrix, whereas the output values represent immunological distance values derived from the phylogenetic tree by averaging the branch lengths connecting taxa. The numbers on the lineages indicate the amount of albumin change along each lineage. The F value is $3.3 \%$. Erophylla can be placed with Phyllonycteris by one-way comparisons.

either has with Brachyphylla. These data support the hypothesis that the Brachyphyllinae as currently conceived forms a natural evolutionary unit. It should also be noted that the Erophylla and Phyllonycteris molecular distances (D = 0.24; AID = 11) are in the general range of those found for congeneric species. From this study, comparisons of Monophyllus plethodon and M. redmani yield values of $\mathrm{D}=0.17$ and $\mathrm{AID}=8$. In addition, an electrophoretic examination (Arnold et al., 1980) of four species of Eptesicus yielded data that suggest either equivalent or more distant relationships between these four congeners (Rogers' D ranged from 0.21 to 0.47 ) than found between E. sezekorni and P. aphylla.

Also of interest is the contrast in degree of difference that distinguishes Brachyphylla from Erophylla and Phyllonycteris at the anatomical and biochemical levels. In spite of the divergence of Brachyphylla, the two biochemical data sets agree in placing Brachyphylla as near to Phyllonycteris and Erophylla as Monophyllus is to Glossophaga (Table 2 and Fig. 2). Anatomically, Monophyllus and Glossophaga are sufficiently similar that Varona (1974) considered them congeneric. Clearly, the magnitude of anatomical distinctiveness is not mirrored in the two biochemical data sets.

Because the brachyphylline genera were sufficiently unique to be accorded subfamilial status and because of an implied long period of isolation, Baker and Genoways (1978) suggested that these genera were the most likely candidates of any of the Antillean bat fauna for having reached the area by vicariance (Rosen, 1978) rather than over water dispersal. However, distance values from both the electrophoretic and albumin studies are not of the magnitude that would be anticipated if the intrasubfamilial radiation was extremely ancient. Comparative data will be needed from 
TABLE 3.-Albumin immunological distances resulting from one-way comparisons of Erophylla and six glossophagine species to the four albumin antisera representing both the subfamilies Glossophaginae and Brachyphyllinae.

\begin{tabular}{lcccc}
\hline & \multicolumn{4}{c}{ Antisera } \\
\cline { 2 - 5 } \multicolumn{1}{c}{ Antigen } & $\begin{array}{c}\text { Mono- } \\
\text { phyllus }\end{array}$ & Glossophaga & Brachyphylla & Phyllonycteris \\
\hline Choeroniscus & 16 & 24 & 27 & 21 \\
Hylonycteris & 22 & 26 & 29 & 17 \\
Leptonycteris & 28 & 23 & 37 & 29 \\
Anoura & 21 & 34 & 26 & 23 \\
Lonchophylla & 44 & 48 & 50 & 48 \\
Lionycteris & 68 & 49 & 53 & 11 \\
Erophylla & 28 & 32 & 23 & \\
\hline
\end{tabular}

other Antillean bat taxa before the significance of values from the Brachyphyllinae can be understood.

Relationship of the Brachyphyllinae to the Glossophaginae.-We next consider the two hypotheses concerning brachyphylline-glossophagine relationships discussed in the introduction. The albumin immunological data do not support the grouping of the Brachyphyllinae, Monophyllus, and Glossophaga into a derived clade possessing a similar karyotype of $2 \mathrm{n}=32, \mathrm{FN}=60$. At least four other glossophagine genera (Choeroniscus, Hylonycteris, Leptonycteris, and Anoura) are more closely aligned to the Glossophaga and Monophyllus lineages than either of these two lineages is to the Brachyphyllinae. Furthermore, these genera can be associated more closely to either the Glossophaga or Monophyllus lineages. These data indicate that the $2 \mathrm{n}=$ $32, \mathrm{FN}=60$ karyotype may be primitive for the entire glossophagine-brachyphylline clade as suggested by Baker and Bass (1979). The Anoura caudifer $(2 \mathrm{n}=30, \mathrm{FN}=$ $60)$, Choeroniscus minor $(2 \mathrm{n}=20, \mathrm{FN}=36)$, and Hylonycteris underwoodi $(2 \mathrm{n}=$ $16, \mathrm{FN}=24$ ) karyotypes are then seen as derived from this primitive pattern. In this same regard, Lonchophylla thomasi $(2 \mathrm{n}=32, \mathrm{FN}=38)$ and Lionycteris spurrelli $(2 \mathrm{n}=28, \mathrm{FN}=50)$ may represent either derived or primitive karyotypic forms. The immunological data indicate that these two genera are the most divergent of all the glossophagine and brachyphylline genera examined; however, the exact relationship between the two genera is more tenuous. It is interesting to note that Gardner (1977) suggested a Lonchophylla-like karyotype as primitive for the glossophagines and our data cannot rule out this alternative.

Overall, the immunological data bring into question two important aspects of brachyphylline-glossophagine relationships. First, these data do not support the hypothesized polyphyletic origin of the glossophagine genera as outlined by Baker (1967). The proposition that two or more glossophagine lineages arose independently from a non-nectar feeding stock is highly suspect. Continued G- and C-chromosome banding studies should add further resolution to the exact relationships of glossophagine genera. Second, these data raise a question as to the coordinate (sister-group) status of the subfamilies Brachyphyllinae and Glossophaginae. An alternative classification would be to relegate the Brachyphyllinae to the status of a tribe within the Glossophaginae, thus emphasizing the fact that the Brachyphyllines are island forms deriving from the basal glossophagine radiation.

\section{ACKNOWLEDGMENTS}

We thank A. Wilson for providing laboratory facilities in which the immunology experiments were performed. J. D. Smith, A. L. Gardner, M. Haiduk, L. Robbins, and R. L. Robbins aided 
by reviewing the manuscript. J. Bickham and J. K. Jones, Jr., helped in collecting specimens. We thank F. Arnold and I. McLean for typing numerous drafts. This study was funded through NSF grant DEB-76-20580, a graduate studies grant from the Graduate School, Texas Tech University to RLH, and the M. Graham Netting Research Fund through a grant from the Cordelia S. May Charitable Trust.

\section{Literature Cited}

ARNOLD, M. L., R. J. BAKER, AND H. H. GeNOWAYS. 1980. Evolutionary origin of Eptesicus lynni. J. Mamm., 61:319-322.

$\rightarrow$ BAKER, R. J. 1967. Karyotypes of bats of the family Phyllostomidae and their taxonomic implications. Southwestern Nat., 12:407428.

1979. Karyology. Pp. 107-155, in Biology of bats of the New World family Phyllostomatidae (R. J. Baker, J. K. Jones, Jr., and D. C. Carter, eds.). Spec. Publ. Mus., Texas Tech Univ., 16:1-441.

BAKER, R. J., AND R. A. BASS. 1979. Evolutionary relationship of the Brachyphyllinae to the glossophagine genera Glossophaga and Monophyllus. J. Mamm., 60:364-372.

Baker, R. J., aND H. H. Genoways. 1978. Zoogeography of Antillean Bats. Pp. 53-97, in Zoogeography in the Caribbean: the 1975 Leidy Medal Symposium (F. G. Gill, ed.). Spec. Publ., Philadelphia Acad. Nat. Sci., 13:1-128.

Cronin, J. E., AND V. M. Sarich. 1975. Molecular systematics of the New World monkeys. J. Human Evol., 4:357-375.

Fitch, W. M., and E. Margoliash. 1967. Construction of phylogenetic trees. Science, 155:279-284.

GARDNER, A. L. 1977. Chromosomal variation in Vampyressa and a review of chromosomal evolution in the Phyllostomatidae (Chiroptera). Syst. Zool., 26:300-318.

MaXson, L. R., AND A. C. Wilson. 1974. Convergent morphological evolution detected by studying proteins of tree frogs in the Hyla eximia species group. Science, 185:66-68.

Patton, J. C., AND R. J. BAKer. 1978. Chromosomal homology and evolution of phyllostomatoid bats. Syst. Zool., 27:449-462.

Prager, E. M., AND A. C. Wilson. 1971. The dependence of immunological cross-reactivity upon sequence resemblance among lysozymes. J. Biol. Chem., 246:7010-7017.

1978. Construction of phylogenetic trees for proteins and nucleic acids: empirical evaluation of alternative matrix methods. J. Mol. Evol., 11:129-142.

RoGERS, J. S. 1972. Measure of genetic similarity and genetic distance. Univ. Texas Publ., 7213:145-153.

RoseN, D. E. 1978. Vicariant patterns and historical explanation in biogeography. Syst. Zool., 27:159-188.

SARICH, V. M. 1969. Pinniped origins and the rate of evolution of carnivore albumins. Syst. Zool., 18:286-295.

SARICH, V. M., AND J. E. CRONIN. 1976. Molecular systematics of the primates. Pp. 141170 , in Molecular anthropology, genes and proteins in the evolutionary ascent of the primates (M. Goodman and R. E. Tashian, eds.) Plenum Press, New York, 466 pp.

SARICH, V. M., AND A. C. WILSON. 1966. Quantitative immunochemistry and the evolution of primate albumins: microcomplement fixation. Science, 154:1563-1566.

SElander, R. K., ET AL. 1971. Biochemical polymorphism and systematics in the genus Peromyscus. I. Variation in the old-field mouse (Peromyscus polionotus). Stud. Genet. VI, Univ. Texas Publ., 7103:49-90.

Silva-TaboadA, G., AND R. H. PINE. 1969. Morphological and behavioral evidence for the relationship between the bat genus Brachyphylla and the Phyllonycterinae. Biotropica, 1:10-19.

VARONA, L. S. 1974. Catalogo de los mamiferos vivientes y extinguidos de las Antillas. Acad. Cien., Cuba, 139 pp.

The Museum and Department of Biological Sciences, Texas Tech University, Lubbock, TX 79409; Departments of Anthropology and Biochemistry, University of California, Berkeley, CA 94720; and Section of Mammals, Carnegie Museum of Natural History Annex, 5800 Baum Blvd., Pittsburgh, PA 15206. Submitted 22 August 1980. Accepted 6 April 1981. 